\title{
Influence of different restorative materials on the stress distribution in dental implants
}

\author{
Carlos-Eduardo Datte ${ }^{1}$, João-Paulo-Mendes Tribst ${ }^{1}$, Amanda-Maria-de Oliveira Dal Piva ${ }^{1}$, Renato-Sussu- \\ mu Nishioka ${ }^{2}$, Marco-Antonio Bottino ${ }^{2}$, Alexandre-Duarte M. Evangelhista ${ }^{3}$, Fabrício M de M. Monteiro ${ }^{4}$, \\ Alexandre-Luiz-Souto Borges ${ }^{2}$
}

${ }^{1}$ DDs, MSc, PhD student at Department of Dental Materials and Prosthodontics, São Paulo State University (Unesp), Institute of Science and Technology, São José dos Campos, SP, Brazil. Avenida Engenheiro Francisco José Longo, Jardim São Dimas, São José dos Campos, SP, Brazil

${ }^{2}$ DDS, MS, PhD, Professor at Department of Dental Materials and Prosthodontics, São Paulo State University (Unesp), Institute of Science and Technology, São José dos Campos, SP, Brazil. Avenida Engenheiro Francisco José Longo, Jardim São Dimas, São José dos Campos, SP, Brazil

${ }^{3}$ Private Pratice at Instituto de Odontologia São Paulo (IOSP), São José dos Campos, SP, Brazil. Av Pensilvânia, Jardim Florida, Jacareí , SP, Brazil

${ }^{4}$ DDs, MSc student at Department of Dental Materials and Prosthodontics, São Paulo State University (Unesp), Institute of Science and Technology, São José dos Campos, SP, Brazil. Avenida Engenheiro Francisco José Longo, Jardim São Dimas, São José dos Campos, SP, Brazil

Correspondence:

Av Engenheiro Francisco José Longo, 777

Jardim São Dimas, São José dos Campos

São Paulo, Brazil. CEP 12245-000

amodalpiva@gmail.com

Datte CE, Tribst JPM, Dal Piva AMO, Nishioka RS, Bottino MA, Evangelhista ADM, Monteiro FMM, Borges ALS. Influence of different restorative materials on the stress distribution in dental implants. J Clin Exp Dent. 2018;10(5):e439-44.

Received: 01/12/2017 Accepted: 21/03/2018

http://www.medicinaoral.com/odo/volumenes/v10i5/jcedv10i5p439.pdf

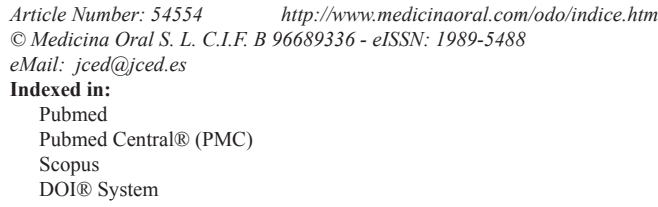

\begin{abstract}
Background: To assist clinicians in deciding the most suitable restorative materials to be used in the crowns and abutment in implant rehabilitation.

Material and Methods: For finite element analysis (FEA), a regular morse taper implant was created using a computer aided design software. The implant was inserted at the bone model with $3 \mathrm{~mm}$ of exposed threads. An anatomic prosthesis representing a first maxillary molar was modeled and cemented on the solid abutment. Considering the crown material (zirconia, chromium-cobalt, lithium disilicate and hybrid ceramic) and abutment (Titanium and zirconia), the geometries were multiplied, totaling eight groups. In order to perform the static analysis, the contacts were considered bonded and each material was assigned as isotropic. An axial load (200 N) was applied on the crown and fixation occurred on the base of the bone. Results using Von-Mises criteria and micro strain values were obtained. A sample identical to the CAD model was made for the Strain Gauge (SG) analysis; four SGs were bonded around the implant to obtain micro strain results in bone tissue.

Results: FEA results were 3.83\% lower than SG. According to the crown material, it is possible to note that the increase of elastic modulus reduces the stress concentration in all system without difference for bone.
\end{abstract}


Conclusions: Crown materials with high elastic modulus are able to decrease the stress values in the abutments while concentrates the stress in its structure. Zirconia abutments tend to concentrate more stress throughout the prosthetic system and may be more susceptible to mechanical problems than titanium.

Key words: Finite element analysis, dental implants, ceramic.

\section{Introduction}

Considering that dental implants present high success rates in the rehabilitation of aesthetic and functional restorations in patients with partial or total dental loss, failures in osseointegration could occur after prosthesis installation (1-3). The use of morse taper implants with 1-2 mm below the alveolar bone crest favors the maintenance of peri-implant tissue (4). When associated with platform switching abutments and masticatory loads, this implant promotes favorable stress dissipation in bone tissue $(5,6)$ with less microstrain in the cervical region (7); it also improves biological sealing with reduction in bone loss (8-10).

The most important reason to investigate the stress distribution in abutments and microstrain in crestal bone around implants is the possibility to provide sufficient information for implant planning, optimizing the implant installation in areas with different bone characteristics (11). In spite of this, masticatory overload is one of the primary factors for fractures and dental implant loss (12). When the clinic uses prosthetic pieces in materials with different elastic modulus, these components can generate different stress and strain in the implant and peri-implant bone $(4,13,14)$. For abutments the most common material used is titanium. Titanium's reliable mechanical behavior and biocompatibility is well-documented in literature (15). Titanium abutments can be defined as the gold standard for implant rehabilitations. An alternative to titanium are zirconia abutments. They present similar survival and improved aesthetics in peri-implant tissue (16). Zirconia partially stabilized by yttrium (YTZP) has excellent mechanical properties (17) such as hardness (1200 HV), corrosion resistance, elastic modulus (210 $\mathrm{MPa})$, flexural strength (900-1200 MPa), compression resistance (2000 MPa), toughness (7-10 MPa), biocompatibility, good soft tissue stabilization and low plaque retention (18-20).

Another important decision for clinicians is the choice of crown material. A large variety of indirect materials exists to manufacture the restorations. Ceramic materials have become a commonly used material for dental prosthesis because it presents aesthetic and long-term resistance (20). Also, the technique of using ceramic crowns onto implants has been proven successfully in the long term (1-3). Considering the rigidity of these materials, the elastic modulus can vary between the modulus of a zirconia to the elastic modulus of a hybrid ceramic with high resilience (21) due to its polymeric matrix.
Regarding all combinations between abutment and ceramic crown, it is not clear to the clinician which one is the best treatment option to dissipate the generated stresses, and thus to ensure greater longevity. The aim of this study was to assist the clinicians in deciding the most suitable restorative materials to be used in implant rehabilitation in the posterior regions. The lower generation of strain in bone tissue and stress in the abutment/ implant set were the guides for this choice aiming for treatment longevity.

\section{Material and Methods}

-Tridimensional model

A regular morse taper internal connection implant (DriveCM Acqua, Neodent, Curitiba, Paraná, Brazil) was created according to the manufacturer's dimensions (4.3 x $10 \mathrm{~mm}$ ), using CAD (Computer Aided Design) software (Rhinoceros 5.0, SR8, McNeel North America, Seattle, WA, USA). Next, the model received an anatomic prosthetic solid abutment. The implant was inserted at the center of a three-dimensional bone model $(40 \times 40$ x $20 \mathrm{~mm}$ ) with $3 \mathrm{~mm}$ of exposed threads. An anatomic cemented prosthesis representing a first upper molar was modeled and placed on the abutment. The mechanical properties of polyurethane were used to simulate bone structure.

-FEA processing

After modeling, the 3D model was imported to analysis software (ANSYS 17.0, ANSYS Inc., Houston, TX, USA). Each material was then assigned as homogeneous, linear and isotropic to perform the static analysis. The information of Young's modulus and Poisson's ratio were selected from the literature (Table 1) (22-26). To simulate absence of joint defects, and all contacts were considered bonded. Group division occurred based on a combination between the crown (4 levels) and abutment ( 2 levels) material, totaling 8 groups.

-Mesh generation

The complex geometry was automatically subdivided in tetrahedral elements that formed the mesh. The number of finite elements was 452,561 with 724,131 nodes. These parameters were achieved with a mesh convergence test $(10 \%)$ to guarantee that the mesh could not interfere in the results (26).

-Loading and fixations

The center of the crown was defined as the loading area according to the defined area in CAD software. An axial load $(200 \mathrm{~N})$ was applied in $\mathrm{Z}$ axis direction (Apical). 
Table 1: Material properties used to perform the static analysis.

\begin{tabular}{|c|c|c|c|}
\hline Material & Poisson's ratio & Elastic modulus (GPa) & References \\
\hline Titanium & 0.35 & 110 & {$[22]$} \\
\hline Zirconia & 0.31 & 205 & {$[23]$} \\
\hline Cr-Co (Chromium-Cobalt) & 0.33 & 218 & {$[24]$} \\
\hline Lithium disilicate & 0.22 & 63.9 & {$[25]$} \\
\hline Hybrid ceramic & 0.28 & 34.7 & {$[25]$} \\
\hline Polyurethane & 0.3 & 3.6 & {$[26]$} \\
\hline
\end{tabular}

The base of the polyurethane block was selected for the system fixation, ensuring movement restriction (26).

-Required results

The results were required according to the failure of ductile solids (27), following Von-Mises criteria. For the peri-implant tissue, the required result was in micro strain based on previous studies that defined these results as important to prevent bone reabsorption $(26,27)$. Any component of the system that presents results with a difference in stress peaks between the groups greater than $10 \%$ will be defined as significant (27).

-In Vitro Strain Gauge

For the in vitro analysis, an identical sample was made following the same characteristics of the 3D model (Fig. 1); four strain gauges (L2A-06-062LW-120; Vishay, Ra-

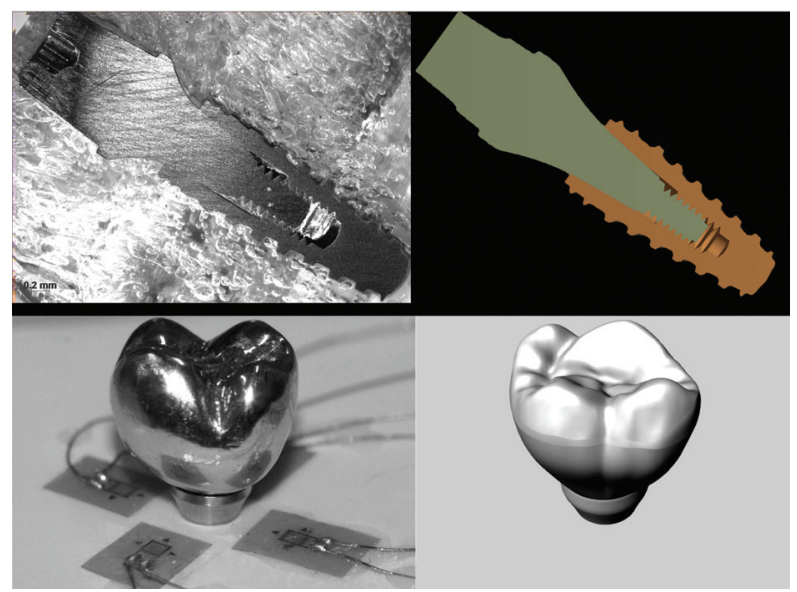

Fig. 1: Experimental sample and three-dimensional model with similar geometries.

leigh, NC, USA) were placed on the surface (polyurethane block) around the implant in locations where relatively large strain values were determined by FEA. The alignment of the gauges was in the direction of maximum strain and parallel to the $\mathrm{X}$ or $\mathrm{Z}$ axis and perpendicular to the $\mathrm{Y}$ axis. Each strain gauge was connected separately, and the four strain gauges were arranged in series to form a one-fourth Wheatstone's bridge. The wires from the strain gauges were connected to a multi- channel bridge amplifier to form one leg of the bridge. A computer (Intel 775P Pentium 4 Q6600; Acer, Mia$\mathrm{mi}, \mathrm{FL}, \mathrm{USA}$ ) was interfaced with the bridge amplifier to record the output signal of the polyurethane surface. Data acquisition system software (System 5000 Model 5100B; Vishay) was used to record the data (27).

-Verification of 3D Model and results validation The selected crown to perform a direct comparison between mathematical (FEA) and experimental (Strain gauge) were the Cr-Co crown due to the facility in manufacturing this material and simplicity for polishing. As the model was identical for the 8 groups and only the elastic modulus changed between them, just one crown needed to be evaluated. The load applied imitates the loading during FEA, in the center of the crown with 200 $\mathrm{N}$ on the universal testing machine (DL-1000; Emic, São José dos Pinhais, PR, Brazil). The magnitude of micro-strain was recorded in $\mu \mathrm{m} / \mu \mathrm{m}$. This procedure was made in triplicate. The mean strain around the implant was calculated and plotted on a bar graph (Fig. 2) ac-

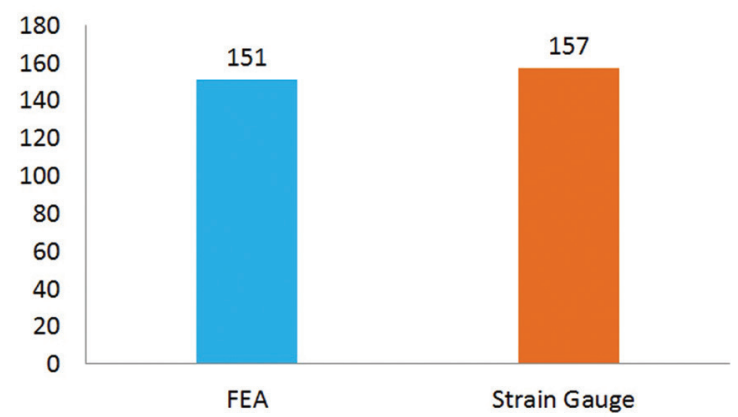

Fig. 2: Bar Graph of strain mean calculated with FEA and strain gauge in cervical region of dental implant.

cording to both the methodologies used in this research to show the consistency between the in vitro and FEA results. The mean of FEA results were 3.83\% lower than strain gauge mean of measurements.

\section{Results}

For Von-Mises stress generated in each group, a qualitative view allows for perceiving an increase in stress 
with zirconia abutments when compared to titanium ones (Fig. 3). According to the crown material, it is possible to note that the increase of elastic modulus reduces the stress concentration in all system (abutment/implant/ bone). With a sagittal view of the implant (Fig. 4), it is possible note that there is no significant difference $(10 \%)$

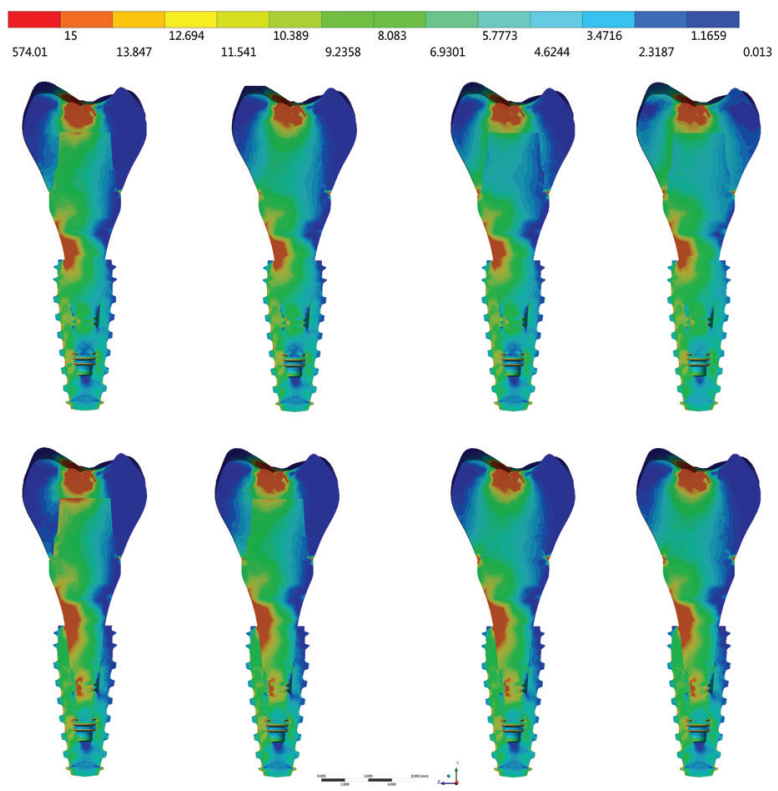

Fig. 3: Von-Mises stress in set. In the first row: groups with titanium abutments; and in the second row: groups with zirconia abutments. From left to right: crowns of hybrid ceramic, lithium disilicate, chrome cobalt and zirconia.


Fig. 4: Sagittal view of Von-Mises stress in the dental implant. In the first row: groups with titanium abutments; and in the second row: groups with zirconia abutments. From left to right: crowns of hybrid ceramic, lithium disilicate, chrome cobalt and zirconia. between the groups from the internal threads of implants. No difference was reported between the groups $(10 \%)$ for the bone micro strain (Fig. 5). The set of restoration (crown, abutment and implant) was divided into three distinct parts and the stress peak of each region was calculated to allow a quantitative comparison between the groups using bar graphs (Fig. 6). The combination of hy-

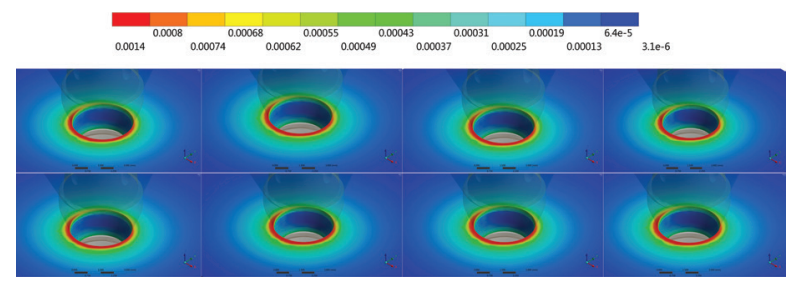

Fig. 5: Perspective view of micro strain in peri-implant tissue. In the first row: groups with titanium abutments; and in the second row: groups with zirconia abutments. From left to right: crowns of hybrid ceramic, lithium disilicate, chrome cobalt and zirconia.

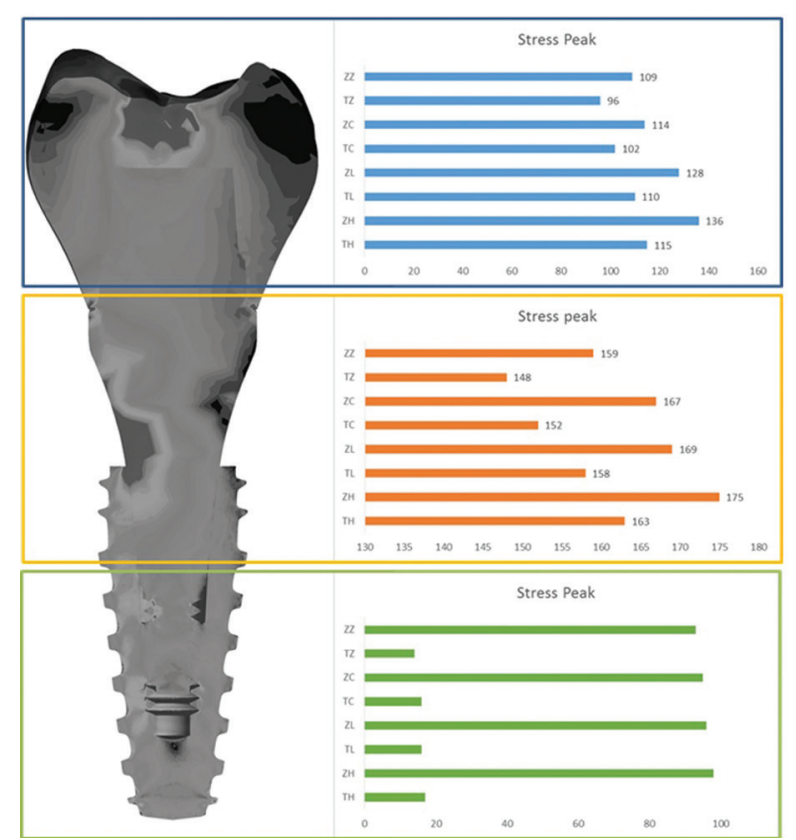

Fig. 6: Stress peak in three different regions of the set: Crown region, Implant's cervical and apical region, according to the groups: $\mathrm{ZZ}$ - zirconia abutment with zirconia crown; $\mathrm{TZ}$ - titanium abutment with zirconia crown; $\mathrm{ZC}$ - zirconia abutment with Cr-Co crown; TC - titanium abutment with Cr-Co crown; ZL - zirconia abutment with lithium disilicate crown; TL - titanium abutment with lithium disilicate crown; $\mathrm{ZH}$ - zirconia abutment with hybrid ceramic crown and $\mathrm{TH}$ - titanium abutment with hybrid ceramic crown.

brid ceramic crown with zirconia abutment presents the worst biomechanical behavior in the crown region and cervical region. For the apical region of the set, the factor "crown material" was not significant and the factor "abutment material' showed a very increased magnitude in stress peaks for all groups with zirconia abutments. 
Both implemented methodologies do not require statistical analysis because FEA consists of a mathematical method with absolute values. In addition, Strain Gauge was used to validate the computational models with the in vitro test using one sample per group. According to the similarity $(3.83 \%)$ of results from FEA and Strain Gauge (Fig. 2), it was possible to observe that the models were considered valid and showing that conclusions only from FEA methods are possible.

\section{Discussion}

Proper treatment planning and a sound understanding of restorative aspects of dental implants can prevent most implant failures $(8,27)$. Although the bone remodeling process is constantly dependent on the masticatory load (28), the overload (29) may cause damage to the alveolar bone, thereby promoting loss of osseointegration (30).

The choice of a restorative material is an important decision because it could influence cases of excessive biting force or parafunctional habits. It could also prevent bone tissue from damage due to the fact that bone behavior depends on load magnitude (28). However, it could also be found in the literature that restorative material has no influence on the implant's survival (1). In the evaluated situation with a morse taper implant, the restorative material seems to have no influence on bone strain. This result favors the clinician who is concerned with the longevity of the treatment, and who can then associate this implant with an aesthetic material. Moreover, the use of zirconia abutments that provide better aesthetics was also not harmful to bone tissue, making it feasible to be used when there is the concern of osseointegration longevity (Fig. 5). These results corroborate with authors who did not find mechanical damage to the bone tissue when using zirconia on implants (29).

The use of an abutment made in zirconia is justified because it is a biocompatible material suitable for maintaining the health of hard and soft tissues (19). Zirconia biocompatibility seems to be more favorable in the perimplant region due to better fiber insertion than titanium $(31,32)$. Despite this, the results in stress suggest that zirconia abutments should be used with caution, since the main region of stress concentration were the abutment's threads (Fig. 3). This may be associated with fracture reports (33) as the maintenance of torque does not appear to be affected (34). No stress was suggested to be a strain promoted by the abutment in the internal threads of the implant (Fig. 4). However, it is worth emphasizing that if the abutment is released due to the concentrated stress in its threads or even fracture, the system biomechanics will be altered and the implant will have unexpected behavior. Considering the crown material, only the regions of the crown itself and the cervical region of the set were influenced by the different elastic modulus (Fig. 6).
The crown in a material with less elastic modulus concentrated less stress on its structure, which more easily stressed the interface with the abutment and the region above the prosthetic connection. Such results are supported by similar findings in previous studies $(21,35)$. This increase in magnitude suggests probability of initial fracture in these regions of stress concentration, in addition to the possibility of debonding due to the heterogeneous passage of stress between abutment and crown. As the elastic modulus of the crown increased, all previously described effects decreased.

Although the evaluated crowns have different fracture strength profiles and even survival due to their microstructure (21), the choice of restorative material can decrease the stress concentration at the interface with the abutment. For example, when the elastic modulus of the crown approximates the elastic modulus of the abutment as in the case of the crown and abutment in zirconia or crown in $\mathrm{Cr}-\mathrm{Co}$ and abutment in titanium. In this way, materials with lower elastic modulus could have better mechanical behavior if they were used with similar abutments, such as hybrid abutments made with perforated ceramic blocks.

The limitations of this study consist in using homogeneous geometries which means an absence of internal defects, and no simulation of factors present in the oral cavity such as temperature, $\mathrm{pH}$ variation or patient's hygiene (29). These limitations do not invalidate the results, but suggest that they should be carefully evaluated and used to complement clinical experience in correlation with other papers. From the obtained results it was possible to validate the 3D model and conclude that:

1. Restorative materials used in the manufacture of monolithic crowns on unitary morse taper implants are not capable of influencing bone strain;

2. Zirconia abutments tend to concentrate more stress throughout the prosthetic system and may be more susceptible to mechanical problems than titanium abutments; 3. The crowns with high elastic modulus are able to decrease the stress values in the abutments, while the crowns with low elastic modulus decrease the stress in the crown.

\section{References}

1. Sahin S, Çehreli MC, Yalçın E. The influence of functional forces on the biomechanics of implant-supported prostheses - a review. J Dent. 2002;30:271-82.

2. Chee W, Jivraj S. Failures in implant dentistry. $\mathrm{Br}$ Dent J. 2007;202:123-9.

3. Cehreli M, Sahin S, Akça K. Role of mechanical environment and implant design on bone tissue differentiation: current knowledge and future contexts. J Dent. 2004;32:123-32.

4. Cibirka RM, Razzoog ME, Lang BR, Stohler CS. Determining the force absorption quotient for restorative materials used in implant occlusal surfaces. J Prosthet Dent. 1992;67:361-4.

5. Van Staden RC, Guan H, Loo YC. Application of the finite element method in dental implant research. Comput Methods Biomech Biomed Engin. 2006;9:257-70. 
6. Kopp CD. Overdentures and osseointegration. Case studies in treatment planning. Dent Clin North Am. 1990;34:729-39.

7. Tabata LF, Rocha EP, Barão VA, Assunção WG. Platform switching: biomechanical evaluation using three-dimensional finite element analysis. Int J Oral Maxillofac Implants. 2011;26:482-91.

8. Canullo L, Rosa JC, Pinto VS, Francischone CE, Götz W. Inward-inclined implant platform for the amplified platform-switching concept: 18-month follow-up report of a prospective randomized matched-pair controlled trial. Int J Oral Maxillofac Implants. 2012;27:927-34.

9. Tribst JPM, Dal Piva AMO, Borges ALS. Biomechanical tools to study dental implants: A literature review. Braz Dent Sci. 2016;19:5-11. 10. Hürzeler M, Fickl S, Zuhr O, Wachtel HC. Peri-implant bone level around implants with platform-switched abutments: preliminary data from a prospective study. J Oral Maxillofac Surg. 2007;65:33-9.

11. Ko YC, Huang HL, Shen YW, Cai JY, Fuh LJ, Hsu JT. Variations in crestal cortical bone thickness at dental implant sites in different regions of the jawbone. Clin Implant Dent Relat Res. 2017;19:440-46. 12. Lee JH, Lee W, Huh YH, Park CJ, Cho LR. Impact of Intentional Overload on Joint Stability of Internal Implant-Abutment Connection System with Different Diameter. J Prosthodont 2017. doi: 10.1111/ jopr.12661. [Epub ahead of print]

13. Sertgoz A. Finite Element Analysis Study of the Effect of Superstructure Material on Stress Distribution in an Implant-Supported Fixed Prosthesis. Int J Prosthodont. 1997;10:19-27.

14. Ciftçi Y, Canay S. The effect of veneering materials on stress distribution in implant-supported fixed prosthetic restorations. Int J Oral Maxillofac Implants. 2000;15:571-82.

15 Foong JK, Judge RB, Palamara JE, Swain MV. Fracture resistance of titanium and zirconia abutments: an in vitro study. J Prosthet Dent. 2013;109:304-12.

16. Oh SH, Kim SG. Effect of abutment shade, ceramic thickness, and coping type on the final shade of zirconia all-ceramic restorations: in vitro study of color masking ability. J Adv Prosthodont. 2015;7:36874.

17.Piconi C, Maccauro G. Zirconia as a ceramic biomaterial. Biomaterials. 1999;20:1-25.

18. Hisbergues M, Vendeville S, Vendeville P. Zirconia: Established facts and perspectives for a biomaterial in dental implantology. J Biomed Mater Res B Appl Biomater. 2009;88:519-29.

19. Nevins M, Camelo M, Nevins ML, Schupbach P, Kim DM. Pilot clinical and histologic evaluations of a two-piece zirconia implant. Int J Periodontics Restorative Dent. 2011;31:157-63.

20. Dal Piva AMO, Contreras LPC, Ribeiro FC, Anami LC, Camargo SEA, Jorge AOC et al. Monolithic ceramics: Effect of finishing techniques on surface properties, bacterial adhesion and cell viability. Oper Dent. 2018;43:315-25.

21. de Kok P, Kleverlaan CJ, de Jager N, Kuijs R, Feilzer AJ. Mechanical performance of implant-supported posterior crowns. J Prosthet Dent. 2015;114:59-66.

22. Benzing UR, Gall H, Weber H. Biomechanical aspects of two different implant-prosthetic concepts for edentulous maxillae. Int J Oral Maxillofac Implants. 1995;10:188-98.

23. Pereira AHA, Venet M, Tonnesen T, Rodrigues JA. Desenvolvimento de um equipamento para a caracterização não-destrutiva dos módulos elásticos de materiais cerâmicos em geral. Cerâmica. 2010;56:118-122.

24. Rubo JH, Capello Souza EA. Finite-element analysis of stress on dental implant prosthesis. Clin Implant Dent Relat Res. 2010;12:10513.

25. Ramos Nde C, Campos TM, Paz IS, Machado JP, Bottino MA, Cesar PF et al. Microstructure characterization and SCG of newly engineered dental ceramics. Dent Mater. 2016;32:870-8.

26. Tribst JPM, Morais DC, Alonso AA, Dal Piva AMO, Borges ALS. Comparative three-dimensional finite element analysis of implant-supported fixed complete arch mandibular prostheses in two materials. J Indian Prosthodont Soc. 2017;17:255-260.

27. Simonis P, Dufour T, Tenenbaum H. Long-term implant survival and success: a 10-16-year follow-up of non-submerged dental implants. Clin Oral Implants Res. 2010;21:772-7.
28. Frost HM. A2003 update of bone physiology and Wolff's Law for clinicians. Angle Orthod. 2004;74:3-5.

29. Isidor F. Influence on peri-implant bone. Clin Oral Implants Res. 2006;2:8-18

30. Frost HM. Wolff Lay and bone's structural adaptations to mechanical usage an overview for clinicians. Angle Ortod. 1994;64:175-88. 31.Scarano A, Assenza B, Piattelli M, Thams U, San Roman F, Favero GA et al. Interimplant distance and crestal bone resorption: a histologic study in the canine mandible. Clin Implant Dent Relat Res. 2004;6:150-6.

32.Welander M, Abrahamsson I, Berglundh T. The mucosal barrier at implant abutments of different materials. Clin Oral Implants Res. 2008;19:635-41

33. Bottino MA, Rocha RFV, Anami LC, Özcan M, Marques de Melo R. Fracture of Zirconia Abutment with Metallic Insertion on Anterior Single Titanium Implant with Internal Hexagon: Retrieval Analysis of a Failure. Eur J Prosthodont Restor Dent. 2016;24:164-168.

34. Alikhasi M, Monzavi A, Bassir SH, Naini RB, Khosronedjad N, Keshavarz S. A comparison of precision of fit, rotational freedom, and torque loss with copy-milled zirconia and prefabricated titanium abutments. Int J Oral Maxillofac Implants. 2013;28:996-1002.

35. Kaleli N, Sarac D, Külünk S, Öztürk Ö. Effect of different restorative crown and customized abutment materials on stress distribution in single implants and peripheral bone: A three-dimensional finite element analysis study. J Prosthet Dent. 2017;S0022-3913:30214-7.

Acknowledgements

None.

\section{Conflicts of interest}

Authors denied conflicts of interest of any kind. 